\title{
Phenolic constituents of Trifolium resupinatum var. minus: Protection against rosiglitazone induced osteoporosis in type 2 diabetic male rats
}

\author{
Mona E. S. Kassem ${ }^{1 *}$, Mona M. Marzouk ${ }^{1}$, Amani A. Mostafa ${ }^{2}$, Wagdy K. B. Khalil ${ }^{3}$, Hoda F. Booles ${ }^{3}$ \\ ${ }^{1}$ Department of Phytochemistry and Plant Systematics, National Research Centre, 33 El Bohouth St., Dokki, Giza, Egypt. \\ ${ }^{2}$ Department of Ceramics, Laboratory of Nanomedicine and Tissue Engineering, National Research Centre, 33 El Bohouth St., Dokki, Giza, Egypt. \\ ${ }^{3}$ Department of Cell Biology, National Research Centre, 33 El Bohouth St., Dokki, Giza, Egypt.
}

\section{ARTICLE INFO}

Article history:

Received on: 26/12/2016

Accepted on: 09/03/2017

Available online: 30/05/2017

Key words:

Persian clover,

Thiazolidinediones, diabetes, serum bone markers, bone

mineral density, osteogenic

genes, phytoestrogens.

\begin{abstract}
Thiazolidinediones, an antidiabetic drug, promote bone loss and provoke fractures, suggesting a protective role of phytoestrogens rich herbal supplement along with rosiglitazone. The aqueous methanol extract (AME) of Trifolium resupinatum L. var. minus Boiss. (Fabaceae) and defatted AME (DAME) protective effects were assessed against rosiglitazone (Ros) inducing osteoporosis in type 2 diabetic male rats. Eighty male Albino rats (10/group) were used. OPG, RANKL and $\beta 2$ - microglobulin serum levels, femur BMD (Dexa) and OC, COL and ACP5 osteogenic genes mRNA (qRT-PCR) were evaluated in Ros-rats + AME or DAME (24, 12, 6 mg/kg bw/d, each). Ros-rats + DAME (24 mg/kgbw) revealed the most significant effects on bone biomarkers. It modulated OPG $\left(\mathrm{ng} \mathrm{mL}^{-1}\right)$, RANKL $\left(\mathrm{pg} \mathrm{mL}^{-1}\right)$ and $\beta 2$ - microglobulin $\left(\mu \mathrm{g} \mathrm{mL}^{-1}\right)$ serum levels. It also improved BMD $\left(\mathrm{mg} \mathrm{cm}^{-2}\right)$ of proximal, distal and total femur bones compared to Ros-rats and up-regulated OC and COL and down-regulated ACP5 expressions. The phenolics of bioactive extract (DAME) were evaluated. Twelve known phenolics were isolated and characterized by chromatographic, chemical and spectral techniques. Their HPLC profiling was also analyzed and showed major phenolics; chlorogenic acid > formononetin> quercetin> pseudobaptigenin. DAME in combination therapy with rosiglitazone provides protective effect on bone, possibly due to its phenolics.
\end{abstract}

\section{INTRODUCTION}

Natural products, particularly plant extracts containing phenolics, are being explored for their protective effects against a variety of disease and disorders, including osteoporosis. Among the various phenolics, flavonoids have been reported to improve bone mineral density (BMD) and bone formation (Ma et al., 2008; Weaver, 2012). Isoflavones are a group of flavonoids called phytoestrogens that structurally resemble endogenous estrogens. It has been found to apply prospective health benefits in hormone dependent and age-related diseases, including cancer, cardiovascular disease, menopausal symptoms and osteoporosis (Wu et al., 2003). Phytoestrogens plays an important role in

\footnotetext{
* Corresponding Author
}

Mona El Said Kassem, 1Department of Phytochemistry and Plant Systematics, National Research Centre, 33 El Bohouth St., Dokki, Giza, Egypt.E-mail:monakassem111 @ hotmail.com bone remodeling (Setchell and Lydeking-Olsen, 2003) and also upregulate bone morphogenetic protein BMP2 gene transcription (Zhou et al. 2003). Isoflavones are found in a number of plant species, predominately in the members of legumes (Stahl et al., 1998). The genus Trifolium L. belongs to subfamily Faboideae (=Papilinoideae) of family Fabaceae (=Leguminosae), including about 300 species, widely distributed in subtropical and temperate regions of both hemispheres (Sabudak and Guler, 2009).

Some of Trifolium species are source of phytoestrogens, among them, the well-known one; Trifolium pratense L. (red clover) which is used for the manufacture of herbal drugs and as an alternative to the conventional hormonal replacement therapy (Kolodziejczyk-Czepas, 2012). The major constituents reported from the genus Trifolium are flavonoids, mainly isoflavones (Kazakov et al., 1973; Oleszek et al., 2007; Janda et al., 2009; Sabudak and Guler, 2009; Kicel and Wolbiś, 2012; Dabkevičienè et al., 2012), in addition to limited amount of fatty acids, clovamids, triterpenes, cyanogenic glucosides and phenolic acids 
(Oleszek et al., 2002; Sabudak et al., 2007; 2008a, b; 2009; Kolodziejczyk-Czepas, 2012). Trifolium species have been used in many countries as forage plants and for treatment of numerous diseases, such as eczema, psoriasis, fever, pneumonia, skin problems, sore throat, lung illnesses, stomachache, meningitis, diarrhea and swelling (Kolodziejczyk-Czepas, 2012). They have been also administered as analgesic, antiseptic, expectorant, and sedative (Sabudak et al., 2008b). An anti-diabetic activity has been reported for the seeds of T. alexandrinum L. growing in Egypt (Khaled et al., 2000). There are few available data for the biological action and phytoestrogen contents of some Trifolium species, among them the Persian clover; T. resupinatum growing wild in Egypt. The alcohol extract of the aerial parts of $T$. resupinatum L. var. microcephalum Zoh. showed antiinflammatory and antioxidant activities in arthritic rats (Sabudak $e t$ al, 2008a), while the hexane extract of T. resupinatum L. var. resupinatum $\mathrm{L}$. seeds revealed antioxidant action (Sabudak et al,. 2009). Recently, several interesting finding on pharmacological effects and ethnomedicinal value of $T$. resupinatum have been reported; decoction of whole plant is used for whooping cough, skin sores and ulcer and digestive disorders (Renda et al., 2013; Sharma and Rana, 2014). Flowers are also used as sedative and to treat coughs (Gulshan et al., 2012; Kizilarslan and Özhatay, 2012).

From the phytochemical point of view; four flavonoids were reported from T. resupinatum var. microcephalum (Isik et al., 2007). They are kaempferol 3-O-(6"-acetyl)- $\beta$-Dgalactopyranoside, genistein 7-O- $\beta$-D-glucopyranoside (please justify the distances). formononetin and formononetin 7-O- $\beta-\mathrm{D}$ glucopyranoside. More recently, Janda et al. (2009) isolated nine phenolics from the aerial parts of $T$. resupinatum L. var. majus Boiss. They are represented as, two chlorogenic acids; 3caffeoylquinic acid and 4-caffeoylquinic acid, four quercetin glycosides; quercetin 3-O- $\beta$-D-glucopyranoside, quercetin 3-O(2"- $\beta$ - D glucopyranosyl)- $\beta$-D-galactopyranoside), quercetin 3-O(3"- $\beta$-D-glucopyranosyl) $\quad$ (6"- $\alpha$-L-rhamnopyranosyl)- $\beta$-Dgalactopyranoside and quercetin 3-O-(6"-malonyl)- $\beta$-Dglucopyranoside), two kaempferol glycosides; kaempferol 3-O(2"- $\beta$-D-glucopyranosyl)- $\beta$-D-galactopyranoside and kaempferol $3-O-(3 "-\beta-D-$ glucopyranosyl) $\quad(6 "-\alpha$-L-rhamnopyranosyl)- $\beta-\quad \mathrm{D}$ galactopyranoside, and one isoflavone glycoside; formononetin 7$O-\beta$ - D-glucopyranoside. An alkenol; 4,15-dimethyl-2-(1,2dihydroxyethyl)-hexadecane, and an alkyl glucoside; 1-undecene1-O- $\beta-2^{\prime}, 3^{\prime}, 4^{\prime}, 6^{\prime}$-tetraacetyl gluco-pyranoside, have been isolated from T. resupinatum var. microcephalum (Sabudak et al., 2008b). In addition, few fatty acids were reported for $T$. resupinatum var. resupinatum (Sabudak et al., 2009). Recent studies revealed significant decrease in total BMD in diabetic rats treated with rosiglitazone (Gupta et al., 2010; Zgórka, 2011). It was found that there is a strong correlation between the decrease in BMD, and therapy duration by glitazones (Ha et al., 2010; Schwartz et al., 2006). Thus, there is wide variety of newer therapeutic agents/strategies being examined for the treatment of type 2 diabetes management (T2DM), most of all currently under preclinical and early clinical stages of drug development. In view of the phytochemical and pharmacological properties of Trifolium species, this study was designed to assess the protective effect of the extracts from Egyptian $T$. resupinatum aerial parts against rosiglitazone induced osteoporosis in male rats. In addition, the phenolic constituents of the bioactive extract were investigated as well as the localization of isolated phenolics was determined in the HPLC profile.

\section{MATERIAL AND METHODS}

\section{General}

Streptozotocin was purchased from Sigma- Aldrich Company. Rosiglitazone was provided as a gift from APEX Company (Egypt). It was suspended in $1 \%$ Tween 80. Rosiglitazone was orally administered in a dose of $10 \mathrm{mg} / \mathrm{kg}$ (Elmegeed et al., 2011; Pickavance et al., 1999). NMR experiments were recorded on Jeol EX-500 spectrometer. EIMS was measured on Finnigan-Mat SSQ 7000 spectrometer, while ESIMS on LCQ Advantage Thermo Finnigan spectrometer. UV spectra were recorded on Shimadzu model-2401 CP spectrophotometer. CC was carried out on Polyamide 6S (RiedelDe-Haen AG, Seelze Haen AG, D-30926 Seelze Hanver, Germany) and Sephadex LH-20 (Pharmazia, Uppsala, Sweden). PPC (descending) Whatman No. 1 and $3 \mathrm{MM}$ papers, using solvent systems (1) $\mathrm{H}_{2} \mathrm{O}$, (2) $15 \%$ AcOH ( $\mathrm{AcOH}: \mathrm{H}_{2} \mathrm{O}, 15: 85$ ), (3) $30 \%$ AcOH (AcOH: $\mathrm{H}_{2} \mathrm{O}, 30: 70$ ) (4) BAW (n-BuOH: AcOH: $\mathrm{H}_{2} \mathrm{O}$ 4:1:5, upper layer), and (5) BBPW $\left(\mathrm{C}_{6} \mathrm{H}_{6}: \mathrm{n}-\mathrm{BuOH}\right.$ : pyridine: $\mathrm{H}_{2} \mathrm{O}$, 1:5:3:3, upper layer). HPLC profile was recorded on Agilent HPLC 1200 series equipped with diode array detector (Agilent Technologies, Waldbronn, Germany).

\section{Plant Material and extraction}

T. resupinatum var. minus was freshly collected and identified by Dr. Ibrahim El Garf in April 2009 from Cairo University garden. A voucher specimen (No.446) was deposited in the herbarium of National Research Centre (CAIRC), Egypt. The air-dried powdered $(3 \mathrm{Kg})$ was extracted with $80 \% \mathrm{MeOH}(4 \mathrm{x}$ $10 \mathrm{~L})$. The solvent was evaporated under reduced pressure at $60^{\circ} \mathrm{C}$ afforded $320 \mathrm{~g}$ aqueous methanol extract (AME). AME was defatted with petroleum ether $(4 \times 1 \mathrm{~L})$ yielded $260 \mathrm{~g}$ of defatted aqueous methanol extract (DAME).

\section{Acid hydrolysis}

Acid hydrolysis of DAME was carried by refluxing at $80^{\circ} \mathrm{C}$ for $2 \mathrm{~h}$ in $1.2 \mathrm{M} \mathrm{HCl}$ in $50 \%$ aqueous methanol (Häkkinen $e t$ al., 1999). After hydrolysis, the mixture was extracted three times with EtOAc. The EtOAc extract was concentrated in vacuum to yield the aglycones mixture.

\section{Animals}

Male albino adult rats (100-120g) used in the experiments were purchased from the Animal House Colony, Giza, Egypt. They were maintained on standard laboratory diet (protein, $16.04 \%$; fat, $3.63 \%$; fiber, $4.1 \%$; and metabolic energy, 
$0.012 \mathrm{MJ}$ ) and water ad libitum at the Animal House Laboratory, NRC, Egypt. After an acclimation period of 1 week, animals were grouped and housed individually in filter-top polycarbonate cages, temperature-controlled $\left(23 \pm 1^{\circ} \mathrm{C}\right)$ and artificially illuminated $(12 \mathrm{~h}$ dark/light cycle) room free from any source of chemical contamination. All animals received human care in compliance with the guidelines of the Animal Care and Use Committee of NRC, Egypt (09085).

\section{Oral toxicity of $T$. resupinatum}

Acute oral toxicity of AME of T. resupinatum var. minus was investigated. Two groups of six rats in each, were administrated orally the AME (1.2 and $120 \mathrm{mg} / \mathrm{kg} \mathrm{bw}$, respectively). A group of animals treated with vehicle served as control. There were no visible signs of toxicity or mortality in the two groups during and after $7 \mathrm{~d}$ of treatment. Accordingly, it was promising to go on the study.

\section{Experimental design}

Eighty rats were divided into eight groups with ten rats in each group. The groups were as follows: G1; healthy rats treated orally with saline (Control), G2-G8 are diabetic rats received orally rosiglitazone $(10 \mathrm{mg} / \mathrm{kg} \mathrm{bw})$ (Ros-rats). Experimental diabetes was induced by a single-dose of (45 mg/kg bw, intraperitoneally, ip) streptozotocin (STZ) injection according to the method described by Patil et al. 2011. G2; Ros-rats, G3-G5; Ros-rats orally treated with $\operatorname{AME~}(6,12$ and $24 \mathrm{mg} / \mathrm{kg}$ bw) and G6-G8; Ros-rats orally treated with DAME (6, 12 and $24 \mathrm{mg} / \mathrm{kg}$ bw). Rosiglitazone, AME and DAME were suspended in $1 \%$ tween and given each as single doses orally to the rats once per day for $30 \mathrm{~d}$ (Gupta et al., 2010).

\section{Sample Collections}

At the end of the experimental period, blood samples from fasting rats were withdrawn from retro-orbital venous plexus under diethyl ether anesthesia in dry clean centrifuge tubes. Blood samples were centrifuged at $3000 \mathrm{rpm}$ for $15 \mathrm{~min}$ at $4^{\circ} \mathrm{C}$ where the clear sera were separated and immediately stored at $-20{ }^{\circ} \mathrm{C}$ in a clean plastic eppendorf until analyses. The animals were then rapidly sacrificed and the right femurs were harvested. Each right femur bone was carefully cleaned; length and weight were recorded and then stored in formalin buffer $10 \%$ for dual energy X-ray absorptiometry (DEXA). BMD of each right femur were measured by DEXA using Norland XR46, version 3.9.6/2.3.1 instrument (Norland X-R-46 version 3.9.6, Peachtree City, GA, USA) equipped with dedicated software for small animal measurements. This technique provided an integrated measure of right femur proximal, distal and total areas.

\section{Analytical Determinations}

Serum osteoprotegerin (OPG) and receptor activator of nuclear factor- $\kappa \mathrm{B}$ Ligand (RANKL) levels were determined by enzyme linked immunosorbent assay (ELISA) technique using $\mathrm{R}$ and D Elisa (Sorin Biomedica, Eti-System, Denlay Instruments
Ltd, England) kit (O'Brien et al., 2001; Teng et al., 2002).While serum $\beta 2$-microglobulin level was assayed by ELISA procedure using International Immuno-Diagnostics kit (Orgentec Diagnostika GmbH, Mainz, Germany) (Crisp et al., 1983).

\section{Expression of osteogenic genes Isolation of total RNA}

Total RNA was extracted from the bone samples obtained from the intertrochanteric region of the proximal femur of male rats by the standard TRIzol ${ }^{\circledR}$ Reagent extraction method (Invitrogen, Germany). Briefly, bone samples were pulverized under liquid nitrogen and homogenized in $1 \mathrm{~mL}$ of TRIzol ${ }^{\circledR}$ Reagent. Afterwards, the homogenized sample was incubated for $15 \mathrm{~min}$ at room temperature. A volume of $0.2 \mathrm{~mL}$ of chloroform per $1 \mathrm{~mL}$ of TRIzol® Reagent was added. Then the samples were vortexed vigorously for $15 \mathrm{sec}$ and incubated at room temperature for $3 \mathrm{~min}$. The samples were centrifuged for no more than 12,000 $\mathrm{x} g$ for $15 \mathrm{~min}$ at $4^{\circ} \mathrm{C}$. After centrifugation, the mixture was separated into lower red, phenol-chloroform phase, an interphase, and a colorless upper aqueous phase. RNA was remained exclusively in the aqueous phase. Therefore, the upper aqueous phase was carefully transferred without disturbing the interphase into a fresh tube.

The RNA which was often invisible before centrifugation was precipitated forming a gel-like pellet from the aqueous phase by mixing with isopropyl alcohol. A volume of $0.5 \mathrm{~mL}$ of isopropyl alcohol was added per $1 \mathrm{~mL}$ of TRIzol ${ }^{\circledR}$ Reagent used for the initial homogenization. Afterwards, the samples were incubated at 15 to $30^{\circ} \mathrm{C}$ for $10 \mathrm{~min}$ and centrifuged at not more than $12,000 \mathrm{x} g$ for $10 \mathrm{~min}$ at $4^{\circ} \mathrm{C}$. The RNA was precipitated which was often invisible before centrifugation, formed a gel-like pellet on the side and bottom of the tube. The supernatant was removed completely. The RNA pellet was washed once with $1 \mathrm{~mL}$ of $75 \%$ ethanol.

The samples were mixed by vortexing and centrifuged at no more than $7,500 \times g$ for $5 \mathrm{~min}$ at $4^{\circ} \mathrm{C}$. The supernatant was removed and RNA pellet was air-dried for 10 minutes. RNA was dissolved in diethylpyrocarbonate (DEPC) treated with water by passing solution a few times through a pipette tip. Total RNA was treated with $1 \mathrm{U}$ of RQ1 RNAse-free DNAse (Invitrogen, Germany) to digest DNA residues, re-suspended in DEPC-treated water. Purity of total RNA was assessed by the $260 / 280 \mathrm{~nm}$ ratio (between 1.8 and 2.1).

Additionally, integrity was assured with ethidium bromide-stain analysis of $28 \mathrm{~S}$ and $18 \mathrm{~S}$ bands by formaldehydecontaining agarose gel electrophoresis. Aliquots were used immediately for reverse transcription (RT).

\section{Reverse transcription $(R T)$ reaction}

Complete Poly $(\mathrm{A})^{+}$RNA isolated from male rat bone samples was reverse transcribed into cDNA in a total volume of 20 $\mu \mathrm{L}$ using Revert Aid $^{\mathrm{TM}}$ First Strand cDNA Synthesis Kit (MBI Fermentas, Germany) based on previously published methods (Khalil and Booles, 2011; Kassem et al., 2016). 
Table 1: Sequences of primers of the osteogenic genes.

\begin{tabular}{cccc}
\hline Genes & & Sequence 5' to 3 & Accession no. \\
\cline { 2 - 4 } & Forward primer & Reverse primer & \\
\hline OC & CCAGCGGTGCAGAGTCCAGC & GACACCCTAGACCGGGCCGT & NM_199173.3 \\
COL1A1 & AGCGGACGCTAACCCCCTCC & CAGACGGGACAGCACTCGCC & NM_000088.3 \\
ACP5 & GATCTCCAAGCGCTGGAACT & TGGTCTGTGGGATCTTGAAGTG & Logar et al., 2007 \\
TUB- $\beta$ & GAGGGCGAGGACGAGGCTTA & TCTAACAGAGGCAAAACTGAGCACC & NM_001069.2 \\
$\beta$-actin & GGAGATTACTGCCCTGGCTCCTA & GACTCATCGTACTCCTGCTGCTG & Deng et al., 2008 \\
\hline
\end{tabular}

OC; Osteocalcin, COL; Collagen, ACP5; Acid phosphatase, TUB- $\beta$; Tubulin $\beta$.

\section{qRT-PCR and calculation of gene expression}

PCR reactions and calculation of gene expression were analysed according to the method of Kassem et al., (2016). The qRT-PCR of osteogenic genes; osteocalcin (OC), collagen (COL) and acid phosphatase 5 (ACP5) were normalized on the bases of tubulin $\beta$ (TUB- $\beta$ ) and $\beta$-actin expression (Table 1 ).

\section{Phytochemical investigation of DAME \\ Isolation and identification of phenolics}

The DAME was subjected to Polyamide CC $(5.5 \times 125 \mathrm{~cm})$ eluted with $\mathrm{H}_{2} \mathrm{O}$ and followed by $\mathrm{MeOH} / \mathrm{H}_{2} \mathrm{O}$ mixtures of decreasing polarity. A total of 49 fractions were collected, each $250 \mathrm{~mL}$; these were controlled by $\mathrm{PC}$ to give four main fractions [FA $\left(20-40 \% \mathrm{MeOH} / \mathrm{H}_{2} \mathrm{O}\right), \mathrm{FB}\left(50-60 \% \mathrm{MeOH} / \mathrm{H}_{2} \mathrm{O}\right), \mathrm{FC}(70-$ $\left.80 \% \mathrm{MeOH} / \mathrm{H}_{2} \mathrm{O}\right)$ and $\left.\mathrm{FD}\left(90 \% \mathrm{MeOH} / \mathrm{H}_{2} \mathrm{O}-100 \% \mathrm{MeOH}\right)\right]$. FA was chromatographed on Sephadex CC $(2.5 \times 85 \mathrm{~cm})$ using $\mathrm{H}_{2} \mathrm{O}: \mathrm{MeOH}(1: 1)$ as eluent yielding four main subfractions, each was subjected to PPC using $15 \% \mathrm{AcOH}, \mathrm{H}_{2} \mathrm{O}$ and $\mathrm{BAW}$, followed by Sephadex CC using $100 \% \mathrm{MeOH}$ to yield compounds 4 and $\mathbf{8}$ 11. $\mathrm{PPC}$ using $\mathrm{BAW}$ and $15 \% \mathrm{AcOH}$ (double solvent) of $\mathrm{FB}$ afforded compounds 6 and 7. Repeating Sephadex CC $(2.5 \times 85 \mathrm{~cm})$ of $\mathrm{FC}$ on gradient elution with $\mathrm{MeOH} / \mathrm{H}_{2} \mathrm{O}$ then $100 \% \mathrm{MeOH}$ yielded compounds $\mathbf{2}, \mathbf{3}$ and $\mathbf{1 2}$. FD was also chromatographed on PPC eluted with 50\% AcOH afforded compounds $\mathbf{1}$ and $\mathbf{5 .}$

\section{HPLC profile of DAME.}

One gram of DAME (before and after hydrolysis) were dissolved in $10 \mathrm{~mL}$ methanol of HPLC grade and analyzed by an Agilent HPLC 1200 series equipped with diode array detector. Chromatographic separations were performed using a Waters column C18. The binary mobile phase consisted of (A) acetonitrile and (B) $0.1 \%$ acidified water with formic acid. The elution profile was: $0-1 \mathrm{~min} 100 \% \mathrm{~B}$ (isocratic), $1-30 \mathrm{~min} 100-70 \%$ B (linear gradient), 30-35 min 70-20\% B (linear gradient). The flow rate was $1 \mathrm{~mL} / \mathrm{min}$ and the injection volume was $5 \mu \mathrm{L}$. Chromatograms were recorded at $280 \mathrm{~nm}$.

This analysis enabled the characterization of flavonoids on the basis of their retention time and UV spectra. The isolated compounds were used as reference standards $(0.1 \mathrm{mg} / 10 \mathrm{~mL}$ $\mathrm{MeOH})$ to determine them in DAME and to detect their localization in HPLC profile. Separated phenolic peaks were initially identified by direct comparison of their retention times with those of isolated compounds. Standard solution was then added to the sample and peaks were identified by the observed increase in their intensity (El Souda et al., 2014).

\section{Statistical analysis}

All data were analyzed using the General Liner Models (GLM) procedure of Statistical Analysis System (Aronow et al., 1990) followed by Scheffé-test to assess significant differences between groups. The values are expressed as mean \pm SEM. The statements of significance were based on probability of $\mathrm{P}<0.01$ and $\mathrm{P}<0.05$.

\section{RESULTS}

\section{Serum OPG, RANKL and $\beta 2$-microglobulin levels}

The effect of AME and DAME supplementation on serum OPG, RANKL and $\beta 2$ - microglobulin levels in rosiglitazone-induced osteoporosis in male rats are represented in Table 2. Administration of rosiglitazone to male rats caused significant increase in serum RANKL and $\beta 2$-microglobulin levels associated with significant decrease in serum OPG level in comparison with the healthy control rats. However, Ros-rats + AME showed a significant increase in the serum OPG level at the highest dose only ( $24 \mathrm{mg} / \mathrm{kg} \mathrm{bw})$ and a slight changes in the levels of the other two parameters as compared with Ros-rats. Furthermore, Ros-rats + DAME with all doses revealed highly significant increase in serum OPG level with a concomitant significant decrease in serum RANKL and $\beta 2$-microglobulin levels as compared with the Ros-rats in a dose dependant manner (24 $>12>6 \mathrm{mg} / \mathrm{kg} \mathrm{bw})$.

Table 2: Levels of serum OPG, RANKL and $\beta 2$-microglobulin Ros-rats alone or combined with AME and DAME.

\begin{tabular}{|c|c|c|c|c|}
\hline \multicolumn{2}{|c|}{$\begin{array}{c}\text { Groups treatment } \\
\mathrm{mg} / \mathrm{kg} \text { bw/d }\end{array}$} & $\begin{array}{c}\text { OPG } \\
\text { (ng mL-1) }\end{array}$ & $\begin{array}{c}\text { RANKL } \\
\text { (pg mL-1) }\end{array}$ & $\begin{array}{c}\beta 2- \\
\underset{(\mu \mathrm{g} \text { mL-1 })}{\text { microglobulin }}\end{array}$ \\
\hline \multirow{2}{*}{\multicolumn{2}{|c|}{$\begin{array}{l}\text { Control } \\
\text { Ros-rats }\end{array}$}} & $3.42 \pm 0.32^{\mathrm{a}}$ & $58.220 \pm 07.04^{\mathrm{d}}$ & $0.21 \pm 0.04^{b}$ \\
\hline & & $1.62 \pm 0.26^{\mathrm{c}}$ & $162.42 \pm 11.34^{\mathrm{a}}$ & $0.46 \pm 0.05^{\mathrm{a}}$ \\
\hline \multirow{3}{*}{$\begin{array}{c}\text { Ros-rats + } \\
\text { AME }\end{array}$} & 6 & $1.64 \pm 0.22^{\mathrm{c}}$ & $158.26 \pm 12.08^{\mathrm{a}}$ & $0.38 \pm 0.06^{\mathrm{a}}$ \\
\hline & 12 & $1.84 \pm 0.28^{\mathrm{b}}$ & $152.12 \pm 08.14^{\mathrm{a}}$ & $0.34 \pm 0.04^{\mathrm{ab}}$ \\
\hline & 24 & $1.92 \pm 0.32^{\mathrm{b}}$ & $132.24 \pm 09.16^{\mathrm{b}}$ & $0.31 \pm 0.03^{\mathrm{ab}}$ \\
\hline \multirow{3}{*}{$\begin{array}{l}\text { Ros-rats + } \\
\text { DAME }\end{array}$} & 6 & $1.90 \pm 0.42^{\mathrm{b}}$ & $138.18 \pm 06.42^{b}$ & $0.34 \pm 0.02^{\mathrm{ab}}$ \\
\hline & 12 & $2.14 \pm 0.46^{\mathrm{ab}}$ & $112.36 \pm 08.22^{c}$ & $0.26 \pm 0.05^{\mathrm{b}}$ \\
\hline & 24 & $2.46 \pm 0.44^{\mathrm{ab}}$ & $96.640 \pm 06.12^{c}$ & $0.22 \pm 0.04^{\mathrm{b}}$ \\
\hline
\end{tabular}

\section{Bone mineral density (BMD) levels}

The results show the effect of AME and DAME administration on BMD-proximal, BMD-distal and BMD-total areas of femur bones in rosiglitazone-induced osteoporosis in male rats. The Ros-rats showed significant decrease in BMD of the 
proximal, distal and total measured areas in comparison with the healthy rats. On the other hand, the three measurements of BMD for Ros-rats + AME increased slightly except for the high dose. However, Ros-rats treated with all doses of DAME caused significant increase in BMD $(24>12>6 \mathrm{mg} / \mathrm{kg}$ bw) compared with the Ros-rats (Table 3).

Table 3: BMD in proximal, distal and total areas of femur bones of Ros-rats alone or combined with AME and DAME after 30 days of daily treatment.

\begin{tabular}{|c|c|c|c|c|}
\hline \multicolumn{2}{|c|}{$\begin{array}{c}\text { Groups } \\
\text { treatment } \\
\text { mg/kg bw/d }\end{array}$} & $\begin{array}{c}\text { BMD- } \\
\text { proximal } \\
\left(\mathrm{mg} \mathrm{cm}^{-2}\right)\end{array}$ & $\begin{array}{l}\text { BMD-distal } \\
\left(\mathrm{mg} \mathrm{cm}^{-2}\right)\end{array}$ & $\begin{array}{c}\text { BMD-total } \\
\left(\mathrm{mg} \mathrm{cm}^{-2}\right)\end{array}$ \\
\hline \multicolumn{2}{|l|}{ Control } & $109.6 \pm 14.2^{\mathrm{a}}$ & $111.2 \pm 08.6^{\mathrm{a}}$ & $111.3 \pm 06.4^{\mathrm{a}}$ \\
\hline \multicolumn{2}{|l|}{ Ros-rats } & $82.30 \pm 06.4^{\mathrm{b}}$ & $81.20 \pm 07.2^{\mathrm{b}}$ & $82.10 \pm 04.8^{\mathrm{b}}$ \\
\hline Ros- & 6 & $83.80 \pm 04.6^{\mathrm{b}}$ & $84.20 \pm 06.8^{b}$ & $84.60 \pm 06.2^{b}$ \\
\hline rats + & 12 & $88.20 \pm 10.4^{\mathrm{ab}}$ & $89.40 \pm 08.2^{\mathrm{ab}}$ & $88.80 \pm 11.4^{\mathrm{ab}}$ \\
\hline AME & 24 & $92.40 \pm 08.2^{\mathrm{ab}}$ & $94.60 \pm 10.2^{\mathrm{ab}}$ & $94.20 \pm 10.4^{\mathrm{ab}}$ \\
\hline Ros- & 6 & $94.80 \pm 11.4^{\mathrm{a}}$ & $96.20 \pm 08.8^{\mathrm{a}}$ & $96.60 \pm 09.2^{\mathrm{a}}$ \\
\hline rats + & 12 & $98.40 \pm 12.4^{\mathrm{a}}$ & $97.60 \pm 10.4^{\mathrm{a}}$ & $98.60 \pm 10.8^{\mathrm{a}}$ \\
\hline DAME & 24 & $102.8 \pm 08.6^{\mathrm{a}}$ & $104.6 \pm 10.2^{\mathrm{a}}$ & $106.0 \pm 09.2^{\mathrm{a}}$ \\
\hline
\end{tabular}

\section{Expression changes in osteogenic genes}

The qRT-PCR of osteogenic genes (OC, COL and ACP5) is summarized in Figure 1. The results revealed that Rosrats showed significantly lower expression values of $\mathrm{OC}, \mathrm{COL}$ genes in comparison with the healthy male rats. While, Ros-rats treated with AME at $24 \mathrm{mg} / \mathrm{kg}$ bw caused significant increase in OC and COL expression compared with Ros-rats. Moreover, all doses of DAME caused significant increase in OC and COL expression as compared with the Ros-rats, in which the highest expression levels of $\mathrm{OC}$ and COL genes were showed in the high dose of DAME. In the term of ACP5 gene, the present work revealed that the Ros-rats showed significantly higher expression values of ACP5 mRNA in comparison with the healthy male rats. However, Ros-rats treated with AME showed that only the high dose of AME decreased significantly ACP5 expression compared with the Ros-rats.

Moreover, all doses of DAME caused significant decrease in ACP5 expression as compared with the Ros-rats, in which the lowest expression levels of ACP5 gene were showed in Ros-rats treated with AME ( $24 \mathrm{mg} / \mathrm{kg} \mathrm{bw})$.

\section{Phytochemical constituents of DAME Identification of the isolated compounds}

Twelve flavonoids were isolated from DAME (Figure 2). They were identified as quercetin (1), quercetin 3-O- $\beta$ glucopyranoside (2), quercetin 3-O- $\alpha$-rhamnopyranoside (3), rutin (4), Kaempferol (5), daidzein (6), genistein (7), formononetin (8), formononetin7-O- $\beta$-glucopyranoside (9), pseudobaptigenin (10), pseudobaptigenin 7-O- $\beta$-glucopyranoside (11) and chlorogenic acid (12)

The structure elucidation were determined by $\mathrm{R}_{f}$ values, colour reactions, acid hydrolysis, MS spectrometry, UV spectrophotometry (Mabry et al., 1970; Markham, 1982), 1DNMR $\left({ }^{1} \mathrm{H}\right.$ and $\left.{ }^{13} \mathrm{C}\right)$ and 2D-NMR (HMBC and HMQC) spectroscopy. Their spectroscopic data were in agreement with previously reported values (Mabry et al., 1970; Agrawal, 1989; Coward et al., 1993; Markham and Geiger, 1994; Isik et al., 2007; Fedoreyev et al., 2008; Janda et al. 2009). In this study, all phenolics were isolated for the first time from $T$. resupinatum except compounds 2, 8 and 9. To the best of the authors knowledge, no previous phytochemical investigations have been reported on the present variety of $T$. resupinatum (minus).

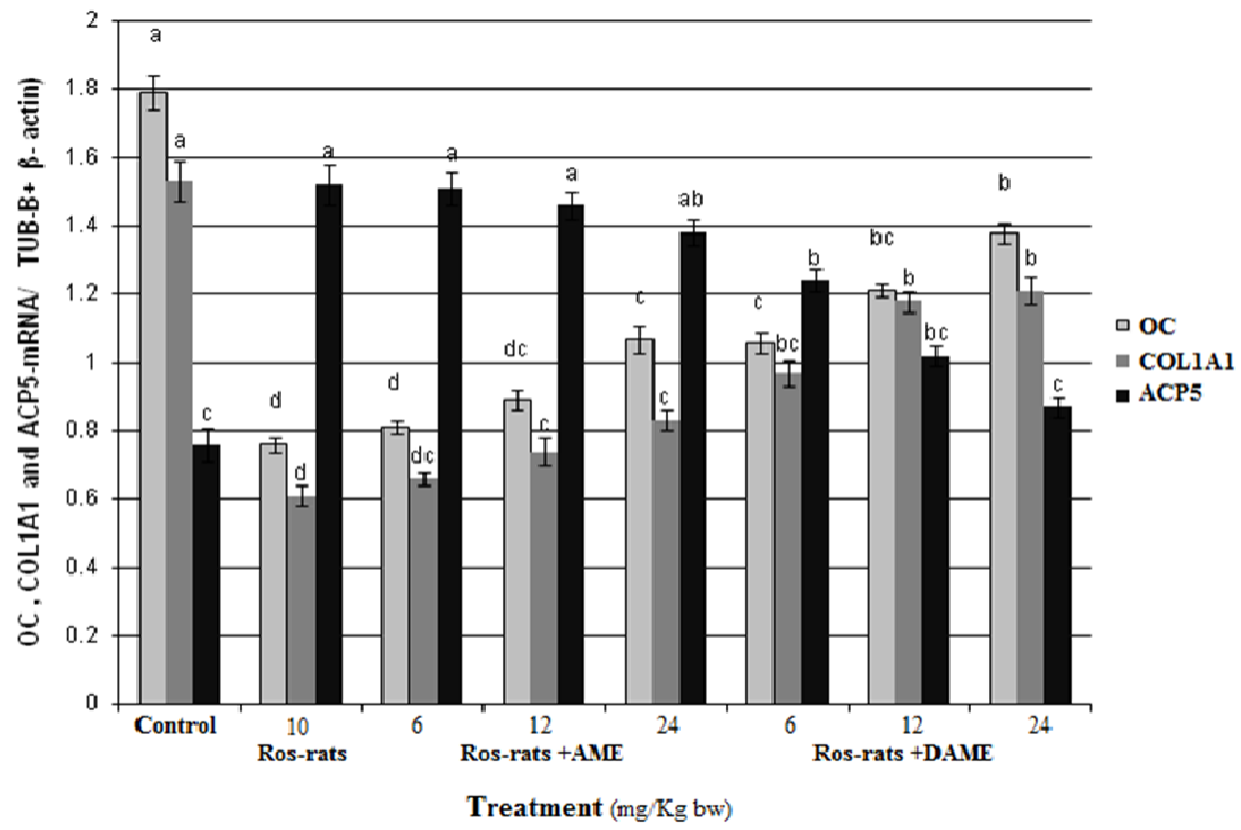

Fig. 1: The alterations of (OC, COL1A1 and ACP5) mRNA in bone tissues isolated from intertrochanteric region of the proximal femur of male rats treated with Rosiglitazone alone (Ros-rats) or combined with $A M E$ and DAME. Data are presented as mean \pm SEM. ${ }^{\text {a,b,c }}$ Mean values within tissue with unlike superscript letters were significantly different $\left({ }^{\mathrm{a}} \mathrm{P}<0.01,{ }^{\mathrm{b}, \mathrm{c}, \mathrm{d}} \mathrm{P}<0.05\right)$. 
<smiles></smiles>

$\mathbf{E}=\mathbf{O H}$

f $\mathbf{R}=\mathbf{H}$

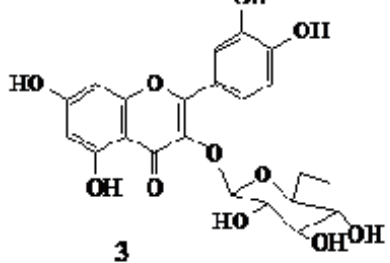<smiles>C=CC(O)=CC=Cc1coc2cc(O)cc(O)c2c1=O</smiles><smiles>O=C(/C=C/c1ccc(O)c(O)c1)C[C@@H]1C[C@@](O)(C(=O)O)C[C@H](O)[C@H]1O</smiles><smiles>O=C(O)C(O)C(O)C(O)Oc1c(-c2ccc(O)c(O)c2)oc2cc(O)ccc2c1=O</smiles>

2: $\mathbf{R}=\mathbf{H}$

4. $R=$ hamnqyranoside<smiles>[R]c1ccc2c(=O)c(-c3ccc([AlH])cc3)coc2c1</smiles>

6: $R 1=R 2=O H$

$8: \mathrm{Rl}=\mathrm{OCH}_{3}, \mathrm{R2}=\mathrm{OH}$

- $\mathrm{Rl}=\mathrm{OCH}_{3}, \mathrm{R} 2=O$ glucopyranosid:<smiles>[X]c1ccc2c(=O)c(-c3ccc4c(c3)OCO4)coc2c1</smiles>

\section{8: $\mathrm{R}=\mathrm{OH}$}

11 $\mathrm{R}-\boldsymbol{O}$ gloropyranoside

Fig. 2: Chemical structural of compounds 1-12. 1) Quercetin , 2) Quercetin 3- $O$ - $\beta$-glucopyranoside, 3) Quercetin 3-O- $\alpha$-rhamnopyranoside, 4) Rutin, 5) Kaempferol, 6) Daidzein, 7) Genistein, 8) Formononetin, 9) Formononetin7-O- $\beta$-glucopyranoside, 10) Pseudobaptigenin, 11) Pseudobaptigenin 7- $O$ - $\beta$ glucopyranoside, 12) Chlorogenic acid
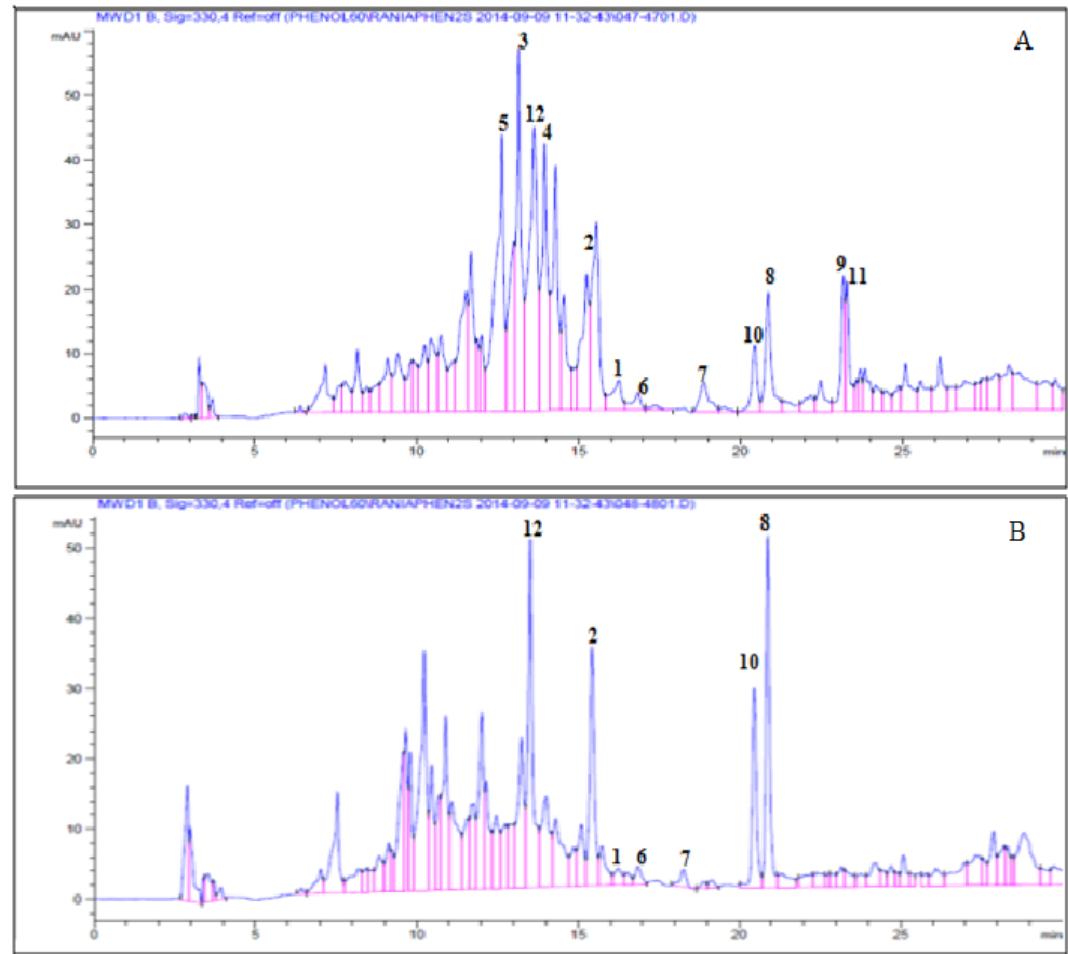

Fig. 3: HPLC at $280 \mathrm{~nm}$ profile of phenolics from T. resipunatum extract DAME (A) before hydrolysis, (B) after hydrolysis. 1) Quercetin , 2) Quercetin 3-O$\beta$-glucopyranoside, 3) Quercetin 3-O- $\alpha$-rhamnopyranoside, 4) Quercetin 3- $O$ - $\beta$-rutinoside, 5) Kaempferol, 6) Daidzein, 7) Genistein, 8) Formononetin, 9) Formononetin7-O- $\beta$-glucopyranoside, 10) Pseudobaptigenin, 11) Pseudobaptigenin 7-O- $\beta$-glucopyranoside, 12) Chlorogenic acid. 


\section{Qualitative HPLC profile of DAME}

The DAME (before and after hydrolysis) was subjected to HPLC analysis (Table 4, Figure 3) using the isolated compounds as standards (each, $0.1 \mathrm{mg} / 10 \mathrm{~mL} \mathrm{MeOH}$, purity approximately 98\%). After hydrolysis, it was found that chlorogenic acid > formononetin > quercetin > pseudobaptigenin are the major phenolic skeletons at retention times 13.64, 20.86, 15.44 and 20.44 with $\%$ area 5.91, 5.57, 4.61 and 3.36, respectively. Moreover, the other skeletons (kaempferol, daidzein and genistein) are represented at retention times 16.19, 16.8 and 18.8 with $\%$ area $0.47,0.42$ and 0.38 , respectively.

Table 4: HPLC analysis of DAME before and after acid hydrolysis.

\begin{tabular}{llll}
\multicolumn{2}{c}{ Flavonoids } & \multirow{2}{*}{ Rt } & \multicolumn{2}{c}{ Area \% } \\
Before & After \\
\hline Quercetin (1) & 15.44 & 1.95 & 4.61 \\
Quercetin 3-O- $\beta$-glucopyranoside (2) & 13.16 & 5.17 & - \\
Quercetin 3-O- $\alpha$-rhamnopyranoside (3) & 13.99 & 4.73 & - \\
Rutin (4) & 12.64 & 3.41 & - \\
Kaempferol (5) & 16.19 & 1.04 & 0.47 \\
Diadazein (6) & 16.8 & 0.51 & 0.42 \\
Genestien (7) & 18.8 & 0.48 & 0.38 \\
Formononetin (8) & 20.86 & 2.54 & 5.57 \\
Formononetin 7-O- $\beta$-glucopyranoside (9) & 23.18 & 1.87 & - \\
Pseudobaptigenin (10) & 20.44 & 1.31 & 3.36 \\
Pseudobaptigenin 7-O- $\beta$-glucopyranoside & 23.29 & 1.47 & - \\
(11) & & & \\
Chlorogenic acid (12) & 13.64 & 2.73 & 5.91 \\
Total & & 27.21 & 20.72 \\
\hline
\end{tabular}

\section{DISCUSSION}

Certain medical treatments may cause series of bone disorders leading to osteoporosis (Abd Jalil et al., 2012). Glitazones (thiazolidinediones) are relatively new antidiabetic drugs used in type 2 diabetes treatments. Rosiglitazone is a high affinity ligand and activator of the peroxisome proliferatorsactivated receptor- $\gamma$ (PPAR- $\gamma$ ). It acts by increasing sensitivity to endogenous insulin and consequently inducing a hypoglycemic effect. Most of the rosiglitazone effects are mediated via this transcription factor (Lecka-Czemik et al., 1999; Lee et al., 2003). It triggers PPAR-2 functions as a principal negative regulator of osteoblast differentiation (Sabudak and Guler, 2009).

Fujioka et al. (2007) suggested that the phytoestrogen daidzein has a specific, sexually dimorphic effect on bone formation and BMD during growth period in mice.

Moreover, Benvenuti et al. (2012) reported that estrogens and androgens in addition to the phytoestrogens genistein and quercetin are able to counteract the negative effects of rosiglitazone on bone. They suggested the possibility of using steroid receptor modulators, such as plant-derived phytoestrogens, which lack evident adverse effects.

In the present study, $T$. resipunatum aerial parts extracts (AME and DAME) were assayed for their protective effects against bone loss induced by roziglitazone in diabetic male rats and phytochemical investigation of phenolic constituents of the bioactive extract was carried out. Ros administration revealed significant bone loss in experimental animals, possibly through its interaction with PPAR- $\gamma 2$ isoforms, which is critical for the regulation of osteoblast and adiposities differentiation (Rzonca et al., 2004). Treatment of Ros-rats with $T$. resipunatum extracts especially DAME showed a dose dependant- significant increase in micro-hardness of bones when compared to Ros-rats. This could be attributed to the resorption/desorption of calcium, phosphorous caused by Ros through supplemented $T$. resipunatum extracts DAME. The treatment also resulted in a significant reduction in serum OPG level. This finding was supported by that of Lazarenko et al. (2007), who reported that Ros affect the level of OPG mRNA and reduce production of OPG from osteoblasts and/or marrow cells of mice. Meanwhile, the DAME administration produced a significant increase in the serum OPG level in Rosrats. Trifolium species rich in isoflavones has direct effect on the osteoblast cells stimulating OPG expression (Cho et al., 2012; Shu-Jem et al., 2013).

Moreover, treatment with Ros in the current study caused a significant elevation in the serum RANKL and $\beta 2$-microglobulin levels. These findings agreed with that of Cho et al. (2012), who reported that rosiglitazone promotes osteoclastogenesis via increasing RANKL, $\beta 2$-microglobulin and decreasing the OPG expression.

The DAME supplementation caused a significant decrease in serum RANKL and $\beta 2$-microglobulin levels in the Ros-rats. It has been reported that significant reduction in serum RANKL level resulted in rats treated with $T$. medium L. and $T$. pratense extracts as compared to that in untreated OVX rats (Cegieła et al., 2012).

Furthermore, our study demonstrates that male Ros-rats showed significantly low levels of OC, COL expression and higher expression of ACP5 mRNA in bone samples compared with healthy rats. This finding is consistent with previous studies by (Cho et al., 2012) that reported rosiglitazone treatment reduced collagen and osteocalcin expression levels in bone marrow cells. However, supplementation of DAME to Ros-rats reversed the effect of Ros on OC, COL and ACP5 expression. Our data demonstrates that DAME supplementation to male Ros-rats was more effective than AME supplementation. It exerts a significant dose dependant protection and intervention against the negative effect of Ros on bones of diabetic animals. These results prompt us to chemically investigate the $T$. resupinatum DAME bioactive extract.

Phytochemical investigation of DAME and its phenolic profile using HPLC analysis (before and after hydrolysis) demonstrated that the phenolic acid; chlorogenic acid, the isoflavones; formononetin and pseudobaptigenin and the flavonol; quercetin are the major constituents (as free aglycons). The effectiveness of DAME supplementation might be attributed to a higher carbohydrate and phenolic contents including phytoestrogens, than in AME. Referring to Setchell and LydekingOlsen (2003) and Yuan et al. (2007), higher carbohydrate content may contribute to the creation of better environment that stimulates the growth of intestinal microflora. This effect is 
responsible for the metabolism of polyphenols including the conversion of glycosides to aglycones (bioactive molecules) and their further conjugation in blood. Examples of these, the isoflavone glycosides formononetin and daidzin are converted to their aglycones (formononetin and daidzein), then to the active equol; daidzein metabolite (Cegieła et al., 2012).

Chlorogenic acid (CGA) is a major constituent of DAME, characterized by its anti-inflammatory and anti-oxidant activities. It protects bone structure from deterioration by exerting positive effects on bone mass, bone micro architecture and bone strength (Hooshmand et al., 2011). CGA inhibits osteoclast differentiation and bone resorption by down-regulation of receptor activator of Nuclear Factor Kappa-B Ligand-Induced Nuclear Factor of Activated T Cells c1Expression (Kwak et al., 2013). CGA dose-dependently inhibited RANKL-mediated osteoclast differentiation in bone marrow macrophages (BMMs) without any evidence of cytotoxicity.

The phytoestrogen quercetin is considered as one of the bioactive anabolic molecules for bone. Wattel et al. (2004) showed that quercetin exert a beneficial effect in bone remodeling not only via inhibiting osteoclast activity, but also via a protective effect on osteoblasts through its antioxidant activity. Furthermore, recent findings reported that at low concentrations, quercetin enhanced osteogenic differentiation via a mechanism independent from estrogen receptor activation (Kim et al., 2006).

Marini et al., 2007 reported that the metabolic balance of bone formation and resorption can be restored by high isoflavone intake. Isoflavones not only suppress bone breakdown but at the same time enhance the new bone formation. Taken together Bhargavan et al. (2009) and Ishimi et al. (2002) studies, they indicated that isoflavones (formononetin and pseudobaptigenin) may positively enhance osteoblast function and bone anabolism probably not only through estrogen-like action but also via interaction with other signaling pathways such as NF-kB or MEKErk pathways depending on the isoflavone metabolite, and this is shown in pre-clinical studies. The present data revealed that formononetin is a main phytoestrogen in DAME, it has structural similarity to $17 \beta$-estradiol and can bind to estrogen receptors in bone tissue. Vandenput and Ohlsson (2009) stated that estradiol levels are more strongly associated with BMD than testosterone levels in adult men.

Our data, yet preliminary, suggest the possibility to counteract the negative effects of TZD on bone using isoflavones rich plant extract such as $T$. resipunatum aerial parts extract, which lack adverse effects.

\section{CONCLUSION}

Therapeutic advantages may be realized through combination regimes. In the present study, administration of DAME to Ros-rats resulted in marked modulation of bone biomarkers RANKL, $\beta 2$-microglobulin and OPG, and improvement of femoral BMD and content, as well as it reversed the effect of Ros on the osteogenic genes OC, COL and ACP5 expression. Twelve phenolic compounds were isolated from the bioactive extract DAME; ten of them were isolated for the first time from $T$. resupinatum. A qualitative HPLC profile elucidates its major phenolics fingerprint (chlorogenic acid, formononetin, quercetin and pseudobaptigenin), which possess potential antioxidant activity and anti-osteoporosis properties in restoring the metabolic balance of bone formation and resorption. The increased risk of bone loss and fractures in TZD users indicated by clinical evidence necessitate more research to elucidate possible therapeutic strategies and improve bone safety.

\section{ACKNOWLEDGMENT}

Financial support and sponsorship: The authors acknowledge the financial support of Science and Technology Development fund (STDF) project no. 5024 and the National Research Centre (NRC) project no. 10010002 .

Conflict of Interests: There are no conflicts of interest.

\section{REFERENCES}

Abd Jalil MA, Shuid AN, Muhammad N. Role of medicinal plants and natural products on osteoporotic fracture healing. Evid Based Complement Alternat Med 2012; 2012: 1-7.

Agrawal PK. 1989. Carbon-13 NMR of flavonoids. New York: Elsevier.

Aronow MA, Gerstenfeld LC, Owen TA, Tassinari MS, Stein GS, Lian JB. Factors that promote progressive development of the osteoblast phenotype in cultured fetal rat calvaria cells. J Cell Physiol 1990; 143: 213-221.

Benvenuti S, Cellai I, Luciani P, Deledda C, Saccardi R, Mazzanti B, Dal Pozzo S, Serio M, Peri A. Androgens and estrogens prevent Rosiglitazone-induced adipogenesis in human mesenchymal stem cells. J Endocrinol Invest 2012; 35: 365-371.

Bhargavan B, Gautam AK, Singh D, Kumar A, Chaurasia S, Tyagi AM, Yadav DK, Mishra JS, Singh AB, Sanyal S, Goel A, Maurya R, Chattopadhyay N. Methoxylated isoflavones, cajanin and isoformononetin, have non-estrogenic bone forming effect via differential mitogen activated protein kinase (MAPK) signaling. J Cell Biochem 2009; 108: 388-399.

Cegieła U, Folwarczna J, Pytlik M, Zgórka G. Effects of extracts from Trifolium medium L. and Trifolium pratense $\mathrm{L}$. on development of estrogen deficiency-induced osteoporosis in rats. Evid Based Complement Alternat Med 2012; Doi: 10.1155/2012/921684.

Cho ES, Kim MK, Son YO, Lee KS, Park SM, Lee JC. The effects of Rosiglitazone on osteoblastic differentiation, osteoclast formation and bone resorption. Mol Cells 2012; 33: 173-181.

Coward L, Barnes NC, Setchell KD, Barnes S. Genistein, daidzein, and their beta-glycoside conjugates: antitumor isoflavones in soybean foods from American and Asian diets. J Agric Food Chem 1993; 41: 1961-1967.

Crisp AJ, Coughlan RJ, Mackintosh D, Clark B, Panayi GS. $\beta 2$ microglobulin plasma levels reflect disease activity in rheumatoid arthritis. J Rheumatol 1983; 10: 954-956.

Dabkevičienė G, Butkutė B, Lemežienè N, Jakštas V, Vilčinskas E, Janulis V. Distribution of formononetin, daidzein and genistein in Trifolium species and their aerial plant parts. Chemija 2012; 23: 306-311

Deng ZL, Sharff KA, Tang NI, Song WX, Luo J, Luo X, He TC. Regulation of osteogenic differentiation during skeletal development. Front Biosci 2008; 13(1): 2001-2021.

El Souda SS, Mohammed RS, Marzouk MM, Fahmy MA, Hassan ZM, Farghaly AA. Antimutagenicity and phytoconstituents 
of Egyptian Plantago albicans L. Asian Pac J Trop Dis 2014; 4: S946S951.

Elmegeed GA, Khalil WKB, Mohareb RM, Ahmed HH, AbdElhalim MM, Elsayed GH. Cytotoxicity and gene expression profiles of novel synthesized steroid derivatives as chemotherapeutic anti-breast cancer agents. Bioorg Med Chem 2011; 19: 6860-6872.

Fedoreyev SA, Bulgakov VP, Grishchenko OV, Veselova MV, Krivoschekova OE, Kulesh NI, Denisenko VA, Tchernoded GK, Zhuravlev YN. Isoflavonoid composition of a callus culture of the relict tree Maackia amurensis Rupr. et Maxim. J Agric Food Chem 2008; 56(16): 7023-7031.

Fujioka M, Sudo Y, Okumura M, Wu J, Uehara M, Takeda K, Hosokawa Y, Yamada K, Ikegami S, Ishim Y, Differential effects of isoflavones on bone formation in growing male and female mice. Metab Clin Exp 2007; 56: 1142-1144.

Gulshan AB, Dasti AA, Hussain S, Atta MI, Amin-ud-Din M. Indigenous uses of medicinal plants in rural areas of Dera Ghazi Khan, Punjab, Pakistan. J Agric Biol Sci 2012; 7:750-762.

Gupta S, Hrishikeshvan HJ, Sehajpal PK. Spirulina protects against Rosiglitazone induced osteoporosis in insulin resistance rats. Diabetes Res Clin Pract 2010; 87: 38-43.

Ha H, Lee HY, Lee JH, Jung D, Choi J, Song KY, Jung HJ, Choi JS, Chang S, Kim C. Formononetin prevents ovariectomy-induced bone loss in rats. Arch Pharm Res 2010; 33: 625-632.

Häkkinen SH, Kärenlampi SO, Heinonen IM, Mykkänen HM, Törrönen AR. Content of the flavonols quercetin, myricetin, and kaempferol in 25 edible berries. J Agric Food Chem 1999; 47: 2274-2279.

Hooshmand S, Chai SC, Saadat RL, Payton ME, BrummelSmith K, Arjmandi BH. Comparative effects of dried plum and dried apple on bone in postmenopausal women. Br Nutr 2011; 106: 923-930.

Ishimi Y, Yoshida M, Wakimoto $\mathrm{S}$, Wu J, Chiba $\mathrm{H}$, Wang $\mathrm{X}$, Takeda K, Miyaura C. Genistein, a soybean isoflavone, affects bone marrow lymphopoiesis and prevents bone loss in castrated male mice. Bone 2002; 31: 180-185.

Isik E, Sabudak T, Oksuz S. Flavonoids from Trifolium resupinatum var microcephalum. Chem Nat Comp 2007; 43: 614-615.

Janda B, Stochmal A, Montoro P, Piacente S, Oleszek W. Phenolics in aerial parts of Persian clover Trifolium resupinatum. Nat Prod Comm 2009; 4: 661-664.

Kassem MES, Ibrahim LF, Hussein SR, El-Sharawy R, ElAnsari MA, Hassanane MM, Booles HF. Myricitrin and bioactive extract of Albizia amara leaves: DNA protection and modulation of fertility and antioxidant-related genes expression. Pharmaceut Biol, 2016; 54(11): 2404-2409.

Kazakov AL, Litvinenko VI, Ammosov AS. Flavonoids of the genus Trifolium. Chem Nat Comp 1973; 9(3): 406.

Khaled MM, Hassanean, HA, Ohtani K, Kasai R, Yamasaki K. Chalcanol glucosides from seeds of Trifolium alexandrinum. Phytochemistry 2000; 53(3): 401-404.

Khalil WKB, Booles HF. Protective role of selenium against over-expression of cancer-related apoptotic genes induced by o-Cresol in rats. Arch Ind Hyg Toxicol 2011; 62:121-129.

Kicel A, Wolbiś M. Study on the phenolic constituents of the flowers and leaves of Trifolium repens L. Nat Prod Res 2012; 26(21):2050-2054

Kim YJ, Bae YC, Suh KT, Jung JS. Quercetin, a flavonoid, inhibits proliferation and increases osteogenic differentiation in human adipose stromal cells. Biochem Pharmacol 2006; 72:1268-1278.

Kizilarslan Ç, Özhatay N. Wild plants used as medicinal purpose in the south part of İzmıt (Northwest Turkey) Turk J Pharm Sci 2012; 9:199-218.

Kolodziejczyk-Czepas J. Trifolium species-derived substances and extracts-biological activity and prospects for medicinal applications. J Ethnopharmacol 2012; 143(1):14-23.

Kwak S, Lee C, Kim J, Mee H, So H, Lee MS, Rho MC, Oh J. Chlorogenic acid inhibits osteoclast differentiation and bone resorption by down-regulation of receptor activator of nuclear factor kappa-B ligandinduced nuclear factor of activated $\mathrm{T}$ cells $\mathrm{c} 1$ expression. Biolog Pharmaceut Bull 2013; 36(11):1779-1786.
Lazarenko OP, Rzonca SO, Hogue WR, Swain FL, Suva LJ, Lecka-Czernik B. Rosiglitazone induces decreases in bone mass and strength that are reminiscent of aged bone. Endocrinol 2007; 148(6): $2669-2680$

Lecka-Czemik B, Gubrij I, Moerman EA. Inhibition of $\mathrm{OSF} 2 / \mathrm{Cb} \mathrm{F}$ A/expression terminal osteoblast differentiation by PPARgamma 2. J Cell Biochem 1999; 74: 357-371.

Lee $\mathrm{CH}$, Olson P, Evans RM. Minireview: lipid metabolism, metabolic diseases, and peroxisome proliferator-activated receptors. Endocrinol 2003; 144: 2201-2207.

Logar DB, Komadina R, Preželj J, Ostanek B, Trošt Z, Marc J. Expression of bone resorption genes in osteoarthritis and in osteoporosis. J Bone Miner Metabol 2007; 25(4): 219-225.

Ma DF, Qin LQ, Wang PY, Katoh. Soy isoflavone intake increases bone mineral density in the spine of menopausal women: metaanalysis of randomized controlled trials. Clin Nutr 2008; 27:57-64.

Mabry TJ, Markham KR, Thomas MB. 1970. The Systematic Identification of Flavonoids. Berlin: Springer.

Marini H, Minutoli L, Polito F, Bitto A, Altavilla D, Atteritano M, Ina H, Çaliş İ, Ersöz T. Effects of the phytoestrogen genistein on bone metabolism in osteopenic postmenopausal women. Ann Intern Med 2007; 146:839-847.

Markham KR, Geiger H. 1994. ${ }^{1} \mathrm{H}-\mathrm{NMR}$ of flavonoids and their glycosides in DMSO-d6. In: Harborne, JB (Ed), The Flavonoids: Advances in Research since 1986. London: Chapman and Hall. p. 441497.

O'Brien EA, Williams JH, Marshall MJ. Osteoprotegerin is produced when prostaglandin synthesis is inhibited causing osteoclasts to detach from the surface of mouse parietal bone and attach to the endocranial membrane. Bone 2001; 28: 208-214.

Oleszek W, Stochmal A, Janda B. Concentration of isoflavones and other phenolics in the aerial parts of Trifolium species. J Agric Food Chem 2007; 55: 8095-8100.

Oleszek W, Stochmal A. Triterpene saponins and flavonoids in the seeds of Trifolium species. Phytochemistry 2002; 61, 165-170.

Patil SB, Ghadyale VA, Taklikar SS, Kulkarni CR, Arvindekar AU. Insulin secretagogue, alpha-glucosidase and antioxidant activity of some selected spices in streptozotocin-induced diabetic rats. Plant Foods Hum Nut 2011; 66(1): 85-90.

Pickavance LC, Tadayyon M, Widdowson PS, Buckingham RE, Wilding JPH. Therapeutic index for Rosiglitazone in dietary obese rats: separation of efficacy and haemodilution. Br J Pharmacol 1999; 128:15701576 .

Renda G, Yalçın FN, Nemutlu E, Akkol EK, Süntar İ, Keleș H, Hiroji Ina, İhsan Çalış g, Tayfun Ersöz b Comparative assessment of dermal wound healing potentials of various Trifolium L. extracts and determination of their isoflavone contents as potential active ingredients. $\mathbf{J}$ Ethnopharmacol 2013; 148(2), 423-432.

Rzonca SO, Suva LJ, Gaddy D, Montague DC, Lecka-Czernik B. Bone is the target for the antidiabetic compound Rosiglitazone. Endocrinol 2004; 145:401-406.

T, Dokmeci D, Ozyigit F, Isik E, Aydogdu N. Antiinflammatory and antioxidant activities of Trifolium resupinatum var. microcephalum extracts in arthritic rats. Asian J Chem 2008a; 20: 1491-1496.

Sabudak T, Guler N. Trifolium L., a review on its phytochemical and pharmacological profile. Phytother Res 2009; 23:439_ 446.

Sabudak T, Isik E, Oksuz S. Lipid constituents of Trifolium resupinatum var. microcephalum. Nat Prod Res 2007; 9: 828-833.

Sabudak T, Isik E, Oksuz S. Two new compounds from Trifolium resupinatum var. microcephalum. J Asian Nat Prod Res 2008b;10: 1017-1021.

Sabudak T, Ozturk M, Goren AC, Kolak U, Topcu G. Fatty acids and other lipid composition of five Trifolium species with antioxidant activity. Pharm Biol 2009; 47: 137-141.

Schwartz AV, Sellmeyer DE, Vittinghoff E, Palermo L, LeckaCzernik B, Feingold KR, Strotmeyer ES, Cummings SR. Thiazolidinedione use and bone loss in older diabetic adults. J Clin Endocrinol Metabol 2006; 91:3349-3354. 
Setchell KD, Lydeking-Olsen E. Dietary phytoestrogens and their effect on bone: evidence from in vitro and in vivo, human observational, and dietary intervention studies. Am J Clin Nutr 2003; 78: 593S-609S.

Sharma P, Rana JC. Assessment of ethnomedicinal plants in Shivalik Hills of Northwest Himalaya, India. Am J Ethnomed 2014; 1:186-205.

Shu-Jem S, Yeh Y, Shyu H. The preventive effect of biochanin A on bone loss in ovariectomized rats: involvement in regulation of growth and activity of osteoblasts and osteoclasts. Evid Based Complement Alternat Med 2013; 2013:1-10.

Stahl S, Chun TY, Gray WG. Phytoestrogens act as estrogen agonists in an estrogen-responsive pituitary cell line. Toxicol Appl Pharmacol 1998; 152:41-48.

Teng YTA, Nguyen H, Gao X, Kong YY, Gorczynski RM, Singh B, Ellen RP, Penninger JM. Functional human T-cell immunity and osteoprotegerin ligand control alveolar bone destruction in periodontal infection. J Clin Invest 2000; 106: R59.

Vandenput L, Ohlsson C. Estrogens as regulators of bone health in men. Nat Rev Endocrinol 2009; 5(8):437-443.

Wattel A, Kamel S, Prouillet C, Petit JP, Lorget F, Offord E, Brazier M. Flavonoid quercetin decreases osteoclastic differentiation induced by RANKL via a mechanism involving NF kappa B and AP-1. J Cell Biochem 2004; 92:285-295.

Weaver CM, Alekel DL, Ward WE, Ronis MJ. Flavonoid intake and bone health. J Nutr Gerontol Geriatr 2012; 31: 239-253.
Wu Q, Wang M, Simon JE. Determination of isoflavones in red clover and related species by high-performance liquid chromatography combined with ultraviolet and mass spectrometric detection. J Chromatog A 2003; 1016: 195-209.

Yuan JP, Wang J H, Liu X. Metabolism of dietary soy isoflavones to equol by human intestinal microflora-implications for health. Mol Nutr Food Res 2007; 51, 765-781.

Zgórka G. Studies on phytoestrogenic and nonphytoestrogenic compounds in Trifolium incarnatum L. and other clover species using pressurized liquid extraction and high performance column liquid chromatography with photodiode-array and fluorescence detection. J AOAC Inter 2011; 94: 22-31.

Zhou S, Turgeman G, Harris SE, Leitman DC, Komm BS, Bodine PV, Gazit D. Estrogens activate bone morphogenetic protein-2 gene transcription in mouse mesenchymal stem cells. Mol Endocrinol $2003 ; 17: 56-66$

\section{How to cite this article:}

Kassem MES, Marzouk MM, Mostafa AA, Khalil WKB, Booles H. Phenolic constituents of Trifolium resupinatum var. minus: Protection against rosiglitazone induced osteoporosis in type 2 diabetic male rats. J App Pharm Sci, 2017; 7 (05): 174-183. 